\title{
Articles
}

\section{Team Teaching Participation Patterns of Homeroom Teachers in English Activities Classes in Japanese Public Elementary Schools}

\section{David Aline \\ Kanagawa University \\ Yuri Hosoda \\ Kanagawa University}

Since Monbukagakusho (Ministry of Education, Culture, Sports, Science and Technology (MEXT)) introduced its new course of study guidelines, most public elementary schools now offer English Activities classes, mostly classes teamtaught by the homeroom teacher (HRT) and an assistant language teacher (ALT). Although team teaching has received a lot of attention in Japan, there are few studies on team teaching at elementary schools. This observational study examines the interaction among HRT, ALT, and students, with a focus on HRTs' participation patterns in the interaction. The data come from six team-teaching English Activities classes in five randomly selected public elementary schools. The data revealed four observable ways HRTs participated: by being (a) a "bystander," (b) a "translator," (c) a "co-learner" of English, or (d) a "co-teacher." The various participation patterns exhibited by the HRTs affected the classroom interaction in distinct ways. Teaching implications for both experienced and novice teachers are discussed.

「総合的な学習の時間」が本格的に開始されて以来多くの公立小学校で英語活動が導入 されてきた。多くの学校では学級担任と外国人指導助手のティームティーチングによる 授業を行っている。日本ではティームティーチングという言葉をよく耳にするが、小学校 
におけるティームティーチングの研究はまだ進んでいない。本稿では、学級担任、外国人 指導助手、児童の英語活動授業における相互行為を検証し、学級担任の相互行為への参加 パターンについて考察する。本研究では公立小学校 5 校 6 教室における英語活動を分析し た。分析の結果、学級担任は(a) 傍観者、(b) 通訳、(c) 生徒 (d) 教師、として授業に参加し ていたことがわかった。また、学級担任のそれぞれの授業参加パターンは教室内相互行為 に様々な影響を与えていることがわかった。学級担任と外国人指導助手は今後どのように ティームティーチングを進めていくべきなのかについて示唆する。

ince Mombukagakusho (MEXT) introduced a new curriculum offering public elementary schools the option of conducting English activities, the majority of schools have started holding what have become known as English Activities classes. Most of these schools offer classes in the form of team teaching by the homeroom teacher (HRT) and an assistant language teacher (ALT). Although team teaching has received a great deal of attention in Japan, the main focus has been on team teaching in high schools and junior high schools (Browne \& Wada, 1998; Tajino \& Walker, 1998; Wada \& Cominos, 1994); little research as of yet has been completed on team teaching in elementary schools. Moreover, most of what is written on teaching English in elementary schools is based on opinion (J-Shine, 2004; Mitsuya, 2003; Murphey, Asaoka, \& Sekiguchi, 2004; Otsu \& Torigai, 2002), and although it is opinion based on experience and knowledge, it still lacks an objective research approach.

\section{Method}

\section{Design}

The data for this study were collected as part of a larger research project on public elementary schools throughout Japan (MEXT Grant No. 16520359). The project is an observational study of what is actually occurring in the English Activities classes in public elementary schools. This research is designed to supplement, rather than replace, other research using different data collection techniques such as questionnaires.

The schools visited were randomly selected from each of the major geographic areas of Japan. At each school the two researchers observed the classes; video- and audio-recorded the classes with two cameras and two audio-recorders; interviewed the main instructors teaching the classes (e.g., ALTs or HRTs), the homeroom teachers, the curriculum designers, and the principal; and collected curriculum and classroom materials used for the English Activities classes. A total of six classes from five schools 
were used to develop the database. The detailed information of each school is shown in Table 1.

Table 1. Elementary School English Activities Database

\begin{tabular}{|c|c|c|c|c|c|c|}
\hline & 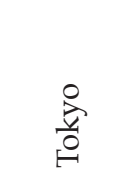 & 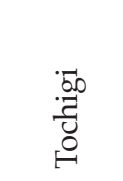 & 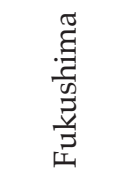 & 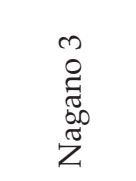 & $\begin{array}{l}10 \\
0 \\
\mathscr{\Xi} \\
\mathbb{\infty} \\
\tilde{Z}\end{array}$ & 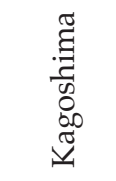 \\
\hline Grade & 4 & 6 & 6 & 3 & 5 & 2 \\
\hline 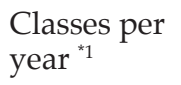 & 20 & 20 & 30 & 5 & 6 & 3 \\
\hline $\begin{array}{l}\text { Years of } \\
\text { English } \\
\text { classes }\end{array}$ & 4 & 3 & 4 & 1 & 3 & 2 \\
\hline $\begin{array}{l}\text { Students } \\
\text { per class }\end{array}$ & 32 & 19 & 28 & 30 & 35 & 12 \\
\hline $\begin{array}{l}\text { Data } \\
\text { collection *2 }\end{array}$ & $\begin{array}{l}\text { Jan. } \\
2004\end{array}$ & $\begin{array}{l}\text { Jan. } \\
2004\end{array}$ & $\begin{array}{l}\text { Sept. } \\
2004\end{array}$ & $\begin{array}{l}\text { Feb. } \\
2005\end{array}$ & $\begin{array}{l}\text { Feb. } \\
2005\end{array}$ & $\begin{array}{l}\text { Feb. } \\
2005\end{array}$ \\
\hline $\begin{array}{l}\text { Main } \\
\text { language of } \\
\text { instruction }\end{array}$ & English & English & English & $\begin{array}{l}\text { English/ } \\
\text { Japanese }\end{array}$ & $\begin{array}{l}\text { English/ } \\
\text { Japanese }\end{array}$ & English \\
\hline
\end{tabular}

${ }^{*} 1$ : The number of classes per year varies depending on the grade level.

*2: The school year in Japan begins in April.

One school we visited for our larger research project was excluded from this study as there was no team teaching for that class since the HRT taught alone. (See Aline \& Hosoda, 2004, 2005; Hosoda \& Aline, 2005 for further details and data from the overall project.) For the purposes of this study, we define team teaching as teaching that includes more than one teacher in the classroom even when only one teacher is in charge of the main interaction. That is to say, team teaching does not require that both, or all, teachers be at the front of the room at all times instructing together all of the classroom activities. ${ }^{1}$ 


\section{Materials}

Close transcripts that include the details of interaction (e.g., loudness, stress, lengthened speech, overlap, etc.) were prepared from the class recordings using the Jefferson transcription system (Jefferson, 1984) as used in Conversation Analysis (CA) (see Appendix for transcription conventions). Conversation Analysis originally began in the field of sociology (e.g., Sacks, 1963, 1972; Sacks, Schegloff, \& Jefferson, 1974; Schegloff, 1968), but has been applied as a research technique in many other fields, including recently in second language acquisition for examining classroom interaction (e.g., He, 2004; Markee, 2000, 2004a, 2004b, 2004c; Mori, 2002; Seedhouse, 2001, 2004). Conversation Analysis looks at the interaction between the participants rather than at the language itself, and requires use of the actual transcription data as evidence for any research findings. This helps to ensure reliability as the readers can independently assess the consistency and interpretation of the analysis.

\section{Analysis}

Analysis of the data revealed four ways HRTs participated in the classes: by being (a) a "bystander," (b) a "translator," (c) a "co-learner" of English, or (d) a "co-teacher."

The bystander participation pattern is indicated by both physical and interactional features. In this pattern, the HRT moves out of the main interactional space at the front of the classroom to a position at the side of the room or to the back of the classroom. The HRT tends to refrain from participating in the main sequence of classroom interaction between the ALT and students. However, the HRT may occasionally enter the interaction when there is some interactional difficulty between the ALT and students.

The translator pattern manifests itself through verbatim translation by the HRT of what the ALT says in the course of using display language or using English for classroom management.

HRTs exhibit a co-learner participation pattern when they are demonstrating to their students through their actions how to be good language learners (Murphey et al., 2004) by, for example, volunteering to give answers to the teacher's questions and modeling the correct form of the answer.

Participation by the HRTs as a co-teacher can be seen when both teachers are in the main sequence of interaction, and directly instructing students as opposed to one teacher repeating through translation what the other teacher has said. 
Although we have given titles to these general categories as they emerged from the analysis of the data, the categories are not discrete but form somewhat of a continuum from little to greater participation in the main interaction by the HRT, or from greater sharing of teaching responsibilities with the ALT to less sharing. However, as will be seen from the analyses, the HRT cannot be placed at one point on the continuum for the entire class as the participation pattern manifests itself on a momentby-moment basis throughout the class session. That is to say, the HRTs did not stick to the same participation pattern during the whole class time. Even in one classroom period, an HRT displayed one participation pattern at one moment of interaction and another pattern at another moment. We will present below some examples of the four patterns with a discussion of some interactional effects.

\section{Teacher as Bystander}

As noted above, the bystander participation pattern is indicated by both physical and interactional features. The HRT moves out of the main interactional space at the front of the classroom to a position at the side of the room or to the back of the classroom. The HRT was performing the role of a "bystander" in the sense that they refrained from participating in the main sequence of classroom interaction between the ALT and students and tended to just observe the interaction. However, the HRT may occasionally participate in the interaction and add a side sequence to the classroom interaction when there is some interactional difficulty between the ALT and students (i.e., an off-the-track sequence such as a repair sequence that helps the interactants to get back to the main sequence of the interaction). For example, in the extract below, the HRT joins in when the class becomes too noisy for the ALT to continue the class.

\section{Extract (1) [Nagano 5: 22]}

((The class is playing a card game. One group of students just gave the correct answer.))

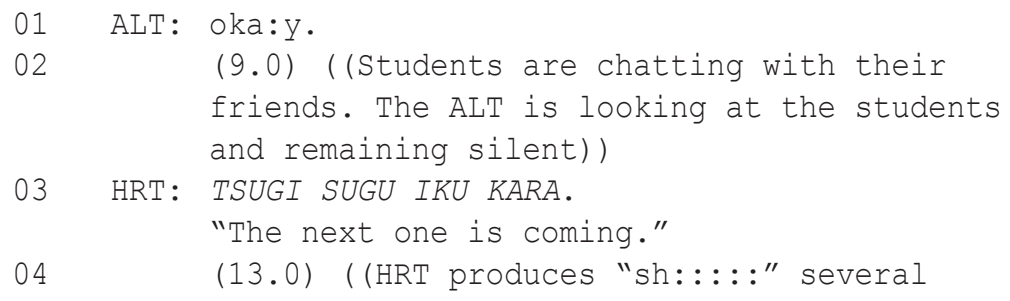




\section{times while the ALT remains silent. Gradually the students become quiet.)) \\ 05 ALT: Ready? It's (.) pink. It's sweet.}

In Extract (1), the class is playing a card game. The students have put their desks together in groups of four and placed a number of picture cards of different types of food face up on their grouped desks. The ALT has given hints in the form of descriptors (e.g., red, sweet) and the students have been competing for selection of the correct picture card. After one group of students gives the correct answer for one card and the ALT accepts the answer in line 1, the class becomes very noisy. The ALT stands quietly in front of the class and simply looks at the students for a while. Then the HRT, who has been silently observing the class from the back of the room, tells the whole class in a loud voice that the next question will be coming soon. However, the students continue chatting and the HRT produces "sh::::::" several times. Finally, the students become silent and the ALT is able to continue the game.

In Extract (1) the HRT entered the classroom interaction to solve an interactional difficulty for the whole class. As shown in Extract (2) below, the bystander HRT may also come into the interaction to solve an interactional difficulty between individual students.

\section{Extract (2) [Tochigi: 8]}

((Student 1 (S1) and Student 2 (S2) are practicing a dialog.))

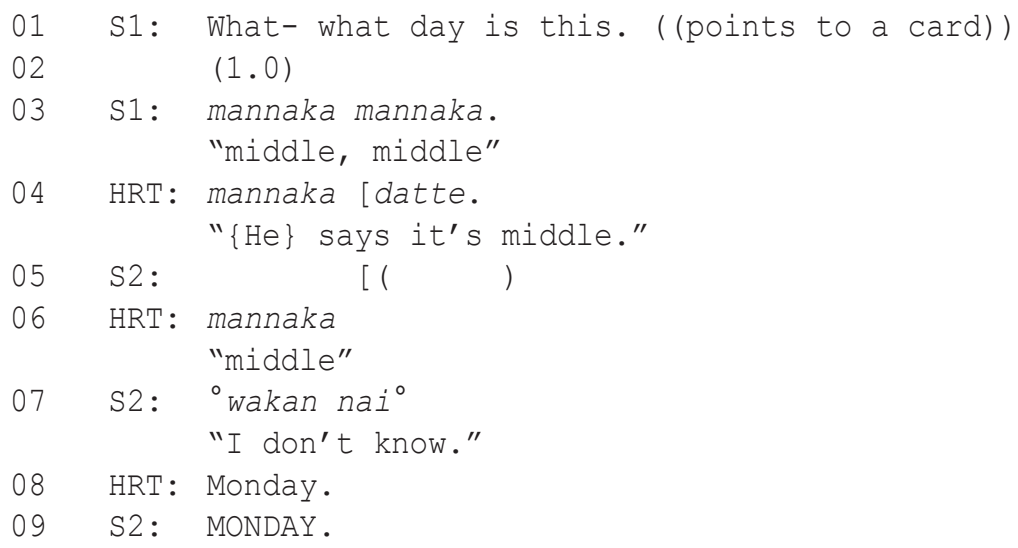


In Extract (2), the students are asking each other for the names of the days of the week. The HRT, who is standing at the side of the classroom next to Student 1 and Student 2, sees that there is a problem in the students' interaction as indicated by their one-second pause in line 2 . The HRT first offers help by repeating twice what S1 said in line 3, "mannaka" (middle). However, as S2 explicitly expresses his nonunderstanding in line 7, the HRT offers the correct answer, "Monday," in line 8. S2 then repeats the correct answer. As demonstrated here, by performing with a bystander participation pattern and positioning himself at the side of the classroom, the HRT was able to deal constructively with problems that individual students were facing.

In sum, being a bystander and positioning him/herself at the side or back of the classroom makes it possible for the HRT to see problems that occur for the class as a whole as well as problems encountered by individual students.

\section{Being a Translator}

The translator pattern manifests itself through verbatim translation by the HRT of what the ALT says in the course of using display language or using English for classroom management. The HRTs in the data often employed this interactional pattern when the students displayed difficulty in understanding what the ALT had said, as shown in Extract 3 below.

\section{Extract (3) [Fukushima: 11]}

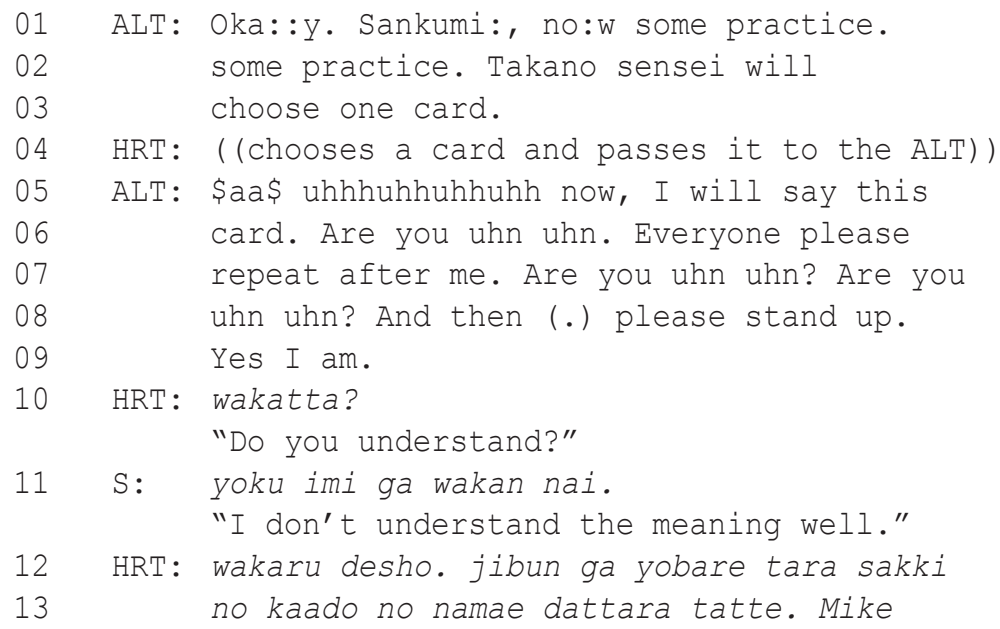


sensei to onaji koto o minna repeat shite

16 ALT: oka:y. First one. Are you Jackie Chan?

In lines 1 to 9, the ALT introduces a new activity in English. Following the HRT's comprehension check (line 10), one student expresses his lack of understanding (line 11). Then in line 12, the HRT starts translating into Japanese what the ALT said. After the translation, the ALT starts the activity. As shown in this example, the HRT's translation helped the students to understand what the ALT said in English and also helped the ALT to move forward with the classroom activities. Therefore the translation played a facilitating role in the classroom.

However, at another place in the data the HRT's translation also occurred when it did not appear to be necessary. Consider Extract (4).

\section{Extract (4) [Fukushima:7]}

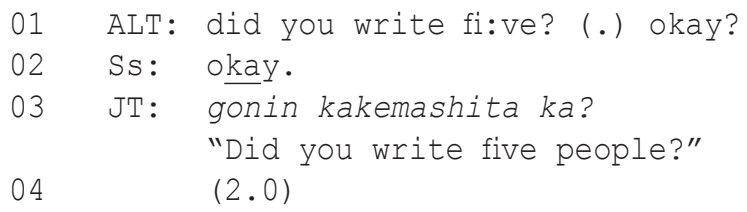

In line 1, the ALT asks the students if they have finished writing the names of five famous people on their papers. In response to the ALT's inquiry, in line 2, the students respond with "okay." This "okay" evidences the students' completion of the task as well as the students' understanding of the ALT's question in English. In line 3, however, the HRT translates into Japanese what the ALT said in line 1. This translated utterance receives no response from the students. Here, the HRT's translation is treated as "unnecessary" by the students.

Translation by the HRT often aided the students and the ALT in that it helped the students' comprehension and enabled the ALT to maintain the momentum of the lesson. Conversely, in some cases, translation occurred at times when it did not appear to be necessary. 


\section{Being a Co-learner}

The HRTs also participated in the classes as co-learners of English with the students. As a co-learner of English, the HRT positioned him/herself with or among the students, facing the ALT, and participated in the activity as a student. By doing so, the HRT demonstrated to the students how to be a good language learner. As a model student, the HRT often volunteered to answer the ALT's questions when no other student answered. An example of this type of participation is shown in Extract (5).

\section{Extract (5) [Nagano 5: 10]}

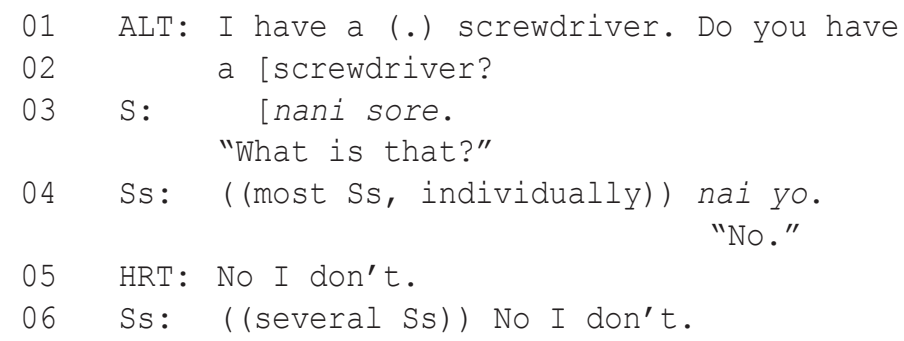

In the extract above, the ALT is asking the students if they have the same things as she is pulling out of her bag. The students are supposed to answer with "Yes, I do" or "No, I don't." When the ALT asks the students if they have a screwdriver, the students respond to the question in Japanese, as shown in lines 3 and 4 . Then in line 5, the HRT provides a model answer in the target language, saying "No I don't," which is repeated by several students in line 6 . In other words, the HRT's answer functioned as a model answer for some of the students, and the students were therefore able to provide an appropriate response to the ALT's question.

However, HRTs acting as model learners may occasionally change the shape of the interaction between the ALT and the students.

\section{Extract (6) [Kagoshima: 9]}

$\begin{array}{lll}01 & \text { ALT: } & \text { Wh } \uparrow \text { at's the wea } \uparrow \text { ther like? } \\ 02 & \text { S1: } & \text { Snow } \underline{y} \\ 03 & \text { HRT: } & \text {.hhh }[\underline{\text { Sno:wy: }} \\ 04 & \text { Ss: } & \text { [ } \text { Sno:wy:. }\end{array}$

In the extract above, the HRT is sitting with the students in a semicircle. They are facing the ALT, who is at the front of the room. In line 
1, the ALT asks the students a display question about the weather. In response, S1 provides the answer with normal turn-taking timing in line 2. By doing so, S1 shows her comprehension of the question as well as demonstrating her ability to use normal turn-taking timing for answering questions in English. On the other hand, the other students wait for the HRT's inbreath, marked in the transcript in line 3 with ".hhh," which indicates she is about to speak, and then answer the ALT's question in chorus with the HRT in line 4. During this question and answer activity, which was repeated many times in this class, all of the students except S1 waited for the HRT's visible and audible inbreath before starting to answer the ALT's question in chorus. Considering that these second-grade students have just started to learn English, the HRT's lead in answering the questions may be beneficial for them in becoming accustomed to speaking English. However, if the HRT continues to control the timing of the answers, the students may become too dependent on her; they may learn more about choral answering in the classroom than about answering questions in normal conversation. It has been reported in the language socialization literature (e.g., Ochs, 1996; Ochs \& Schieffelin, 1984, 1989; Schieffelin \& Ochs, 1986) ${ }^{2}$ that children learn to be competent members of a society through daily routines, and by taking part in daily routines children implicitly receive cultural knowledge through language forms and practices. Thus, by taking part in routines of answering questions in chorus with the HRT, the students may be implicitly receiving the knowledge of language classroom culture. As English is a mandatory subject in Japan and most students will continue to participate in language classrooms for at least the next 10 years, receiving knowledge of language classroom culture may be beneficial. However, it appears that the HRT is more likely socializing the students to the educational technique of language classroom choral repetition than helping them to learn proper turn-taking timing in English. This could have both positive and negative effects in that the students may learn how to participate with others in the learning process, but may also learn to ignore the turn-taking timing and meaning of the language produced.

In short, the HRT's participation in class as co-learner helps students to observe and imitate model responses in English, but at the same time it may alter the timing of the interaction and make the students too dependent on the HRT as part of educational socialization to group learning. 


\section{Being a Co-teacher}

In participation by the HRTs as a "co-teacher" of the class, both the ALT and HRT are in the main sequence of interaction and directly instructing the students. The HRTs most often manifested this pattern on occasions of classroom management (e.g., opening and closing the class session). More pertinently, in some cases, the HRTs co-taught the English activities with the ALT from the front of the class as part of the main interaction. Consider Extract (7) below.

\section{Extract (7) [Tokyo:5:20-6:04]}

((S5, "Yuki," was called on to answer the ALT's question. Ss are sitting in a circle. The HRT is showing a picture card that describes the answer.))

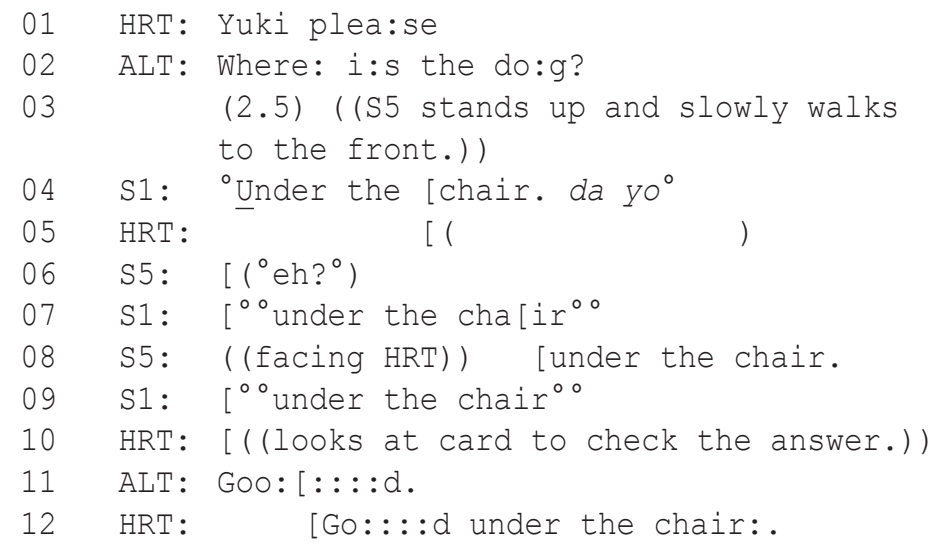

In this extract, both the HRT and ALT are positioning themselves directly in front of the class. In line 1, the HRT summons S5 (Yuki). As the HRT of the class, she knows the names of all the students and it was always the HRT, not the ALT, who called on the students. In response to the HRT's summons and the ALT's question, S5 stands up and slowly walks to the front of the class, where the HRT is holding up a large card with the answers on it; he stops and hesitates. Seeing S5's hesitation, S1 whispers "under the chair" in line 4 and the HRT also whispers something to S5. In line 8, S5 takes a half step forward and finally produces the answer to the ALT's question. However, when S5 answers the question, his gaze and body orientation are on the HRT, not on the ALT, who actually asked the question. By directing his answer to the HRT even though the question came from the ALT, S5 displays his understanding that the HRT is the 
one in the classroom who holds the power to judge the appropriateness of his answer. In fact, during this activity, most of the students who were called on to answer the ALT's questions looked at the HRT when they produced their answers. After S5 answered the question, both the HRT and ALT provided positive feedback. Thus, when HRTs co-teach the class with an ALT - the basic question-answer interactional mechanism, that the one who answers the question should provide an answer to the one who asked the question-is likely to be altered.

\section{Discussion}

As demonstrated above, four types of HRT participation patterns were observed and each participation pattern had some discernible interactional effects. The implications of these effects are discussed in the next section. While these are not the only participation patterns possible for HRTs in the English Activities classes, they are the only patterns that emerged from the data we analyzed. Further observations and analyses may reveal other participation patterns of importance.

Taking the role of a bystander enabled the HRT to deal with the interactional difficulties of the whole class as well as those of individual students, and to help the ALT and students stay on track with the main classroom activities. While the role of bystander may at first appear to be passive, it can serve an important function in the management of classroom interaction. The multitude of functions performed in this role has for the most part been overlooked in research. From our observations and analyses it is apparent that the bystander role, although perhaps misnamed here, serves a significant function in the classroom deserving of further research to look beyond the purely managerial role in order to understand how it may function to further language learning and interaction between the ALT and students.

By translating the ALT's English utterances into Japanese, the HRT helped the students' comprehension and enabled the ALT to continue the lesson. From the viewpoint of increasing comprehensible input, the translation both increases the students' comprehension of the immediate input and increases the overall comprehensible input as it maintains the flow of the lesson. Conversely, the HRT's translation can occur at times when it is not helpful or necessary. When students have already acknowledged their comprehension of the ALT's utterance in English, any translation by the HRT becomes nothing more than a hindrance to the interaction between the ALT and students. 
Through participation in the class as a co-learner, the HRT enabled the students to observe and imitate a good language learner's behavior. Moreover, by repeatedly leading the students in answering the ALT's questions, the HLT was implicitly socializing the students to the language classroom culture. Nevertheless, this practice may result in the students' learning more about choral answering in the classroom than proper turn taking in English. As a co-learner, the HRT must remember that the students do not always view them in that co-learner role. That is, the students will still see the HRT as a teacher and orient to the HRT's role as a teacher in that they will wait for the teacher to lead them in responding to the ALT. Therefore, the HRT, rather than leading and modeling often, needs to also allow the students to take the initiative on their own in responding to the ALT's questions or in other interactions with the ALT.

Finally, when the HRT co-taught the class, the HRT was able to address specific questions to each student on an individual basis. In addition, the HRT was able to maintain the power relationship between students and teacher in the classroom. However, the HRT's participation in the main classroom interaction with the ALT altered the basic question-answer interactional mechanism in which the person who is asked a question is supposed to address the answer to the person who asked the question. Often in our data, the students do not address their answers to the ALT, who asked the question, but to the HRT as the person with institutional power in the classroom. The consequences of this question-answer interactional mechanism for language learning and learning of social interaction needs to become the focus of future research before any conclusions or suggestions for language learning pedagogy can be contemplated.

\section{Implications}

It is difficult and almost dangerous to make suggestions about what teachers should do based on opinion or even based on descriptive observational research. However, there are some suggestions that come out of these analyses that are applicable to teaching, teacher training, and syllabus design.

Teachers, both HRT and ALT, should be aware of the interactional patterns HRTs use in the classroom and the implications of those patterns. Awareness is the first step toward making changes that may lead to improvements in teaching. We do not recommend that teachers video-tape their own classes, transcribe the interaction, and then analyze it for participation patterns-that is simply too time-consuming. But if 
teachers can be made aware of the patterns they and other teachers use and the positive and negative effects associated with those patterns, they can begin to make decisions about their classroom behavior based on the changing interaction on a moment-by-moment basis. Rather than always translating or never translating, they can see that translation is useful when it aids comprehension, but is not useful or may have a negative effect when applied to interactions in which the students have already processed the target language. And they can see that if they participate as bystanders, they are simply turning over the main interaction to the other teacher while continuing to participate as a teacher in terms of classroom management or in the important role of helping individual students.

Students in teacher training programs could watch the video and analyze the transcripts so that they can see how teachers manage the interaction moment by moment as opposed to applying blanket terminology for teaching methods to an entire class session. They could also learn that there are positive and negative aspects to the choices they make as teachers, and therefore learn to balance the possible outcomes of their decisions.

\section{Conclusion}

We have looked at HRTs' interactional patterns in English Activity classes in public elementary schools in Japan. We found that there were basically four interactional patterns and each pattern had both positive and negative effects on the interaction. Those patterns were displayed on a moment-by-moment basis in the classroom interaction.

In this study we limited our observations to analysis of the interaction at the local level, that is, directly between the HRT and ALT or students. Future research should look at how external variables such as school policy, Japanese proficiency levels of ALTs, English proficiency levels of HRTs, years and type of teaching experience, the frequency of English Activities classes, and other variables affect team-taught classes.

\section{Notes}

This paper was supported by MEXT Grant No. 16520359.

1. Furthermore, from analysis of the transcripts it is clear that team teaching in public elementary schools, for the most part, places the ALT at the front of the room managing and instructing the main interaction. This occurs because the HRT is not an English teacher but 
an elementary school teacher who teaches most of the other subjects. The HRT, however, does not turn the entire class session over to the visiting teacher, as the HRT is required as a state licensed teacher to remain in the classroom. Therefore, with the ALT instructing the main interaction, the question remains as to the role of the HRT.

2. The authors argued that language socialization works in two ways: socialization through language and socialization to use the language. What the authors refer to as socialization through language is a process in which novices learn to be competent members of a society through participation in daily routines. By taking part in daily routines, novices implicitly receive cultural knowledge through language forms and practices. On the other hand socialization to use the language is more explicit and it takes place when experts clearly direct novices to use the language according to the social norms.

\section{References}

Aline, D., \& Hosoda, Y. (2004). English activities in Japanese public elementary schools: An observational study. Proceedings of the 9th Conference of Pan-Pacific Association of Applied Linguistics, 15-25.

Aline, D., \& Hosoda, Y. (2005). Observing Japanese public elementary school English activities. JALT 2004 Conference Proceedings, 129-138.

Browne, C., \& Wada, M. (1998). Current issues in high school English teaching in Japan: An exploratory study. Language, Culture and Curriculum, 11 (1), 97-112.

He, A. W. (2004). CA for SLA: Arguments from the Chinese language classroom. Modern Language Journal, 88 (4), 568-582.

Hosoda, Y., \& Aline, D. (2005). Meeting the challenge of English activities in Japanese public elementary schools. The Language Teacher, 29 (4), 15-19.

Jefferson, G. (1984). On the organization of laughter in talk about troubles. In J. M. Atkinson \& J. Heritage (Eds.), Structures of social action: Studies in conversation analysis (pp. 346-369). Cambridge: Cambridge University Press.

J-Shine (2004). Donaru shogakko eigo—hisshuka no yukue [What will happen to elementary school English-movement toward making the subject compulsory]. Tokyo: ALC.

Markee, N. (2000). Conversation analysis. Mahwah, NJ: Laurence Erlbaum.

Markee, N. (2004a). Conversation analysis for second language acquisition. In E. Hinkel (Ed.), Handbook of research in second language teaching and learning (pp. 355-374). Mahwah, NJ: Lawrence Erlbaum.

Markee, N. (2004b). The organization of off-task talk in second language classrooms. In K. Richards \& P. Drew (Eds.), Applying conversation analysis (pp. 197-213). London: Palgrave Macmillan. 
Markee, N. (2004c). Zone of interactional transition in ESL classes. The Modern Language Journal, 88 (4), 583-595.

Mitsuya, T. (2003). Sogotekina gakushu no jikan ni okeru eigokatsudo-ALT to no team teaching no shiten kara [English activities in the period of integrated studies- from the perspective of team teaching with ALTs]. In T. Kanamori (Ed.), Shogakko no eigo kyoiku [English education in elementary schools] (pp. 12-20). Tokyo: Kyoiku Shuppan.

Mori, J. (2002). Task design, plan, and development of talk-in-interaction: An analysis of a small group activity in a Japanese language classroom. Applied Linguistics, 23, 323-347.

Murphey, T., Asaoka, C., \& Sekiguchi, M. (2004). Primary teachers co-learning English with their students. The Language Teacher, 28 (2), 15-18.

Ochs, E. (1996). Linguistic resources for socializing humanity. In J. Gumperz \& S. Levinson (Eds.), Rethinking linguistic relativity (pp. 407-437). Cambridge: Cambridge University Press.

Ochs, E., \& Schieffelin, B. B. (1984). Language acquisition and socialization. In R. Shweder \& R. Levine (Eds.), Culture theory: Essays on mind, self, and emotion (pp, 276-320). Cambridge: Cambridge University Press.

Ochs, E., \& Schieffelin, B. B. (1989). Language has a heart. Text, 9 (1), 7-25. Otsu, Y., \& Torigai, K. (2002). Shogakko de naze eigo? [Why English at elementary schools?]. Tokyo: Iwanami Shoten.

Sacks, H. (1963). Sociological description. Berkeley Journal of Sociology, 8, 1-16.

Sacks, H. (1972). An initial investigation of the usability of conversational data for doing sociology. In D. Sudnow (Ed.), Studies in social interaction (pp. 31-74). New York: Free Press.

Sacks, H., Schegloff, E. A., \& Jefferson, G. (1974). A simplest systematics for the organization of turn-taking for conversation. Language, 50, 696-735.

Schegloff, E. A. (1968). Sequencing in conversational openings. American Anthropologist, 70, 1075-1095.

Schieffelin, B., \& Ochs, E. (1986). Language socialization. Annual Review of Anthropology, 15, 163-191.

Seedhouse, P. (2001). The case of missing "no": The relationship between pedagogy and interaction. In R. Ellis (Ed.), Form-focused instruction and second language learning (pp. 347-385). Malden, MA: Blackwell.

Seedhouse, P. (2004). The interactional architecture of the language classroom: A conversation analysis perspective. Malden, MA: Blackwell.

Tajino, A., \& Walker, L. (1998). Perspectives on team teaching by students and teachers: Exploring foundations for team learning. Language, Culture, and Curriculum, 11 (1), 113-131.

Wada, M., \& Cominos, A. (1994). Studies in team teaching. Tokyo: Kenkyusha. 


\section{Appendix}

\section{Transcription Conventions}

[ ] overlapping talk

$=\quad$ latched utterances

(0.0) timed pause (in seconds)

(.) a short pause

co:lon extension of the sound or syllable

fall in intonation (final)

continuing intonation (non-final)

? rising intonation (final)

CAPITAL loud talk

underline emphasis

$\uparrow \quad$ sharp rise

$\downarrow \quad$ sharp fall

$\circ \quad$ passage of talk that is quieter than surrounding talk

\$ \$ smiley voice

hh audible aspirations

.hh audible inhalations

(( )) comment by the transcriber

( ) problematic hearing that the transcriber is not certain about

" " idiomatic translation of Japanese utterances 
